\title{
Nervi Vascularis
}

National Cancer Institute

\section{Source}

National Cancer Institute. Nervi Vascularis. NCI Thesaurus. Code C33165.

Small nerve fibers that innervate blood vessels. 